SŁAWOMIR JACEK ŻuREK

Katolicki Uniwersytet Lubelski Jana Pawła II

\title{
SPRAWA ROSYJSKA W LITERATURZE POLSKIEJ W IZRAELU Rekonesans
}

Sowiecka Rosja to miejsce kaźni, ale i ocalenia dla wielu polskich Żydów, którzy żyli tam wprawdzie w ciężkich warunkach, ale właśnie tam też przetrwali czas nazistowskiej hekatomby (1939-1945). Z grupy ocalałych na tych terenach wywodzi się przynajmniej kilku ważnych pisarzy polsko-izraelskich. Doświadczenie pobytu w ZSRR $\mathrm{z}$ reguły stało się dla nich istotnym tematem literackich zapisów, a sama Rosja - paradoksalnie - często obiektem ich fascynacji. Wśród późniejszych pisarzy polskojęzycznych aktywnych twórczo w Izraelu prawie trzydziestu (spośród stu ujętych w monografii Literatura polska $w$ Izraelu. Leksykon ${ }^{1}$ ) to ci, którzy wojnę przeżyli w ZSRR ${ }^{2}$. Część z nich stanowili przedwojenni artyści nastawieni

${ }^{1}$ Zob. K. Famulska-Ciesielska, S.J. Żurek, Literatura polska w Izraelu. Leksykon, Budapeszt-Kraków 2012 [dalej: LPI].

2 Wanda Balicka, Ruth Baum, Arie Brauner, Aleksander Czerski, Henryk Dankowicz, Borys Eppel, Eleasar Feuerman, Lipa Fischer, Herbert Friedman, Ignacy Iserles, Jakub Kost, Jan Kot, Szlomo Leser, Tadeusz Lipiński, Leo Lipski, Felicja Mańska, Ilana Maschler, Edward Neuman, Henryk Palmon, Jakub Perelman, Łucja Pinczewska-Gliksman, Szoszana Raczyńska, Aleksander 
lewicowo, niektórzy wręcz o sympatiach komunistycznych. W grupie tej jednak występowali także bundyści, syjoniści oraz zasymilowani polscy inteligenci żydowskiego pochodzenia. Dla wszystkich z nich, niezależnie od predylekcji ideowej, ogromnym szokiem stało się doświadczenie codziennego życia w państwie totalitarnym, a jeszcze większym - aresztowanie i pobyt w lagrach.

\section{Ideowi komuniści}

Większość polskich Żydów zamieszkujących ZSRR w okresie drugiej wojny światowej znalazła się w jego granicach po aneksji wschodnich terenów Rzeczpospolitej przez Armię Czerwoną 17 września 1939 roku. Oprócz nich przybywali tam także ci, którzy mieli świadomość, jaka może być postawa nazistów wobec Żydów na zajętych przez Niemców polskich terenach.

I tak lewicowym przedwojennym intelektualistą był - pochodzący z Sosnowca (tu też uczęszczał do polskiego Gimnazjum Męskiego im. Stanisława Wyspiańskiego) - Henryk Dankowicz (Abraham Chaim Bornsztajn) $)^{3}$ Swoje doświadczenia pobytu w Kazachstanie ${ }^{4}$ odtworzył w autobiograficznej powieści Siódmy wilk (1964), będącej rozrachunkiem $\mathrm{z}$ fascynacją komunizmem, a także opisem przykrego zderzenia wielkich ideałów z ubóstwem życia w wyśnionym państwie Lenina i Stalina. W prozie tej przedstawił również skutki miażdżącej go sowieckiej propagandy oraz zdiagnozował swój stan ostatecznie utraconej wiary w system „sprawiedliwości społecznej”.

Przedwojennym komunistą był także Ignacy Iserles (późniejszy redaktor polskiego czasopisma w Izraelu „Od Nowa”), któ-

Rozenfeld, Kalman Segal, Arnold Słucki, Noe Wertheiser, Israel Zyngman. Zob. LPI.

${ }^{3}$ Zob. np. A. Ben-Asher, Siódmy wilk, „Od Nowa” 1964, nr 14; J. Czapski, A. Vincenz, Dwugłos o Dankowiczu, „Kultura” 1973, nr 11. Podaję za LPI.

${ }^{4} \mathrm{~W}$ Kazachstanie przebywali też inni późniejsi pisarze polsko-izraelscy: Borys Eppel i Jana Gurwic. W azjatyckiej części ZSRR, a dokładnie w Kirgizji, wojnę przeżył Szlomo Leser. 
ry w okresie okupacji sowieckiej pełnił funkcję dyrektora Domu Twórczości Ludowej w Tarnopolu, a następnie naczelnika Wydziału Kadr i Szkolenia w Obwodowym Wydziale Sztuki przy Obywatelskim Komitecie Wyzwolenia. Od 1941 roku, ewakuowany z terenów zajmowanych przez Niemców, przebywał w Kazachstanie oraz w Uzbekistanie. Tam wstąpił do Armii Czerwonej ${ }^{5}$ i szybko zdobył szlify oficerskie. W wojsku sowieckim zajmował się sprawami polskich uchodźców w azjatyckiej części ZSRR. W 1944 roku, jeszcze w Związku Radzieckim, wstąpił do Polskiej Partii Robotniczej (PPR). Po wojnie wrócił do Polski, gdzie związał się z aparatem bezpieczeństwa i sądownictwa, z którego został odsunięty w roku 1953, gdyż jako sędzia Sądu Najwyższego odmówił skazania na śmierć o. Kajetana Raczyńskiego (przeora klasztoru Paulinów na Jasnej Górze). Z Polski wyjechał w 1957. Działalność publicystyczna Iserlesa w Izraelu miała głównie charakter rozliczeniowy z jego zaangażowania się we współpracę z sowieckim systemem władzy w ZSRR i w Polsce.

Trzecim przedwojennym ideowym komunistą był Arnold Słucki (członek Związku Młodzieży Komunistycznej, a następnie Polskiej Partii Robotniczej — PRR, a w końcu Polskiej Zjednoczonej Partii Robotniczej - PZPR), który po wybuchu wojny we wrześniu 1939 przedostał się na tereny okupowane przez Sowietów. Uczył się tam najpierw w ukraińskiej szkole dla nauczycieli we Włodzimierzu Wołyńskim, a następnie ukończył wyższy kurs języka i literatury rosyjskiej oraz ukraińskiej przy Instytucie Doskonalenia Nauczycieli w Łucku. Ewakuował się w głąb Rosji wraz z Armią Czerwoną w lecie 1941, na skutek czego znalazł się w Uzbekistanie. W tym też roku wstąpił do Komsomołu i działał w nim jako instruktor. W grudniu 1942 roku zgłosił się na ochotnika do Armii Czerwonej i służył w niej jako szeregowiec, później został przeniesiony do Ludowego Wojska Polskiego (LWP) jako oficer polityczny. W jego twórczości ${ }^{6}$, szczególnie we wczesnej poezji, „można zauważyć

\footnotetext{
${ }^{5}$ W Armii Czerwonej służył także Aleksander Czerski i Tadeusz Lipiński.

${ }^{6}$ Zob. S.J. Żurek, Dwa oblicza. Arnolda Stuckiego biograficzne i poetyckie doświadczanie Rosji, w: A. Jarzyna, Z. Kopeć (red.), M. Jaworski (współred.), Obraz Rosji w literaturze polskiej XX wieku, Poznań 2014, s. 311-323.
} 
[...] nasycenie motywami rosyjskimi, a właściwie sowieckimi, gdyż zdecydowana ich większość funkcjonuje jedynie w odniesieniu do ideologii komunistycznej i państwa radzieckiego"7. Słucki bardzo gorliwie realizował postulaty poetyki socrealizmu, m.in. nakłaniające do odwoływania się do rzeczywistości radzieckiej. W tym okresie fascynują go szczególni twórcy literatury rosyjskiej (Puszkin, Niekrasow, Majakowski). Sposób postrzegania Rosji zmienia się w jego poezji tworzonej po roku 1956 w Polsce i następnie — po wydarzeniach marca 1968 - na emigracji w Izraelu i w Niemczech. Odszedł od fałszywej apoteozy Rosji jako Kraju Rad, a odkrył ją jako ważne miejsce dla kultury światowej. Inspirowany podróżami po ZSRR (części europejskiej i azjatyckiej), które odbył jeszcze w pierwszej połowie lat 60., opisuje tamtejsze zabytki historyczne, pomniki przyrody, podkreślając wielokrotnie wkład Rosji w rozwój cywilizacji ludzkiej (szczególnie religii, filozofii i literatury). Poeta w tomie Dolina dziwów (1964) często odwołuje się do historii Rosji z ery zarówno średniowiecznej, jak i modernistycznej - tuż przedrewolucyjnej. Także w ostatnich swoich wierszach z tomu Biografia anioła (1982) powraca on do motywów rosyjskich, i - co ciekawe - łączy tam ze sobą dwa doświadczenia osobiste - pobyt w Rosji i w Izraelu jako miejscach, w których nie mógł się zaaklimatyzować, tęskniąc do Polski. Przykładem może być wiersz ${ }^{\star \star \star}$ (Na tym łóżku leżał Gorki...).

\section{Więźniowie łagrów}

O wiele większa grupa przyszłych pisarzy polsko-izraelskich, niż ci bezpośrednio zaangażowani w latach 1939-1945 w system sowiecki, przeszła przez zesłanie i łagry. Taki właśnie los przypadł Lipie Fischerowi, który przez ponad dziesięć lat (1941-1951) był więźniem obozów koncentracyjnych w Ożarkach, Azance, Aszchabadzie, Taszkiencie i Nowosybirsku. Po zwolnieniu z zamknięcia został przymusowo osiedlony na Uralu, gdzie mieszkał aż do 1957 roku. W sumie przeżył w państwie totalitarnym osiemnaście lat.

\footnotetext{
${ }^{7}$ Tamże.
} 
Zarówno w twórczości lirycznej (Wiersze opowiadaja, 1976), jak i prozatorskiej - fabularyzowane wspomnienia napisane w jidysz A Frizirer in Lagier [Fryzjer w lagrze] (1975) oraz Un doch dergrejkt [Mimo wszystko przetrwałem] (1985), przedstawił swoje trudne doświadczenia z tamtego czasu i miejsca.

Podobnie traumatyczny charakter miało spotkanie z Rosją innego późniejszego pisarza polsko-izraelskiego - Filipa Istnera. Został aresztowany przez NKWD już w październiku 1939 roku. Było to dla niego wtedy zupełnie niezrozumiałe, gdyż przed wojną sympatyzował ze środowiskami zwolenników polityki Kraju Rad. Po drobiazgowym i długotrwałym śledztwie, które miało miejsce w więzieniu na lwowskim Zamarstynowie, został zesłany na Syberię. Przez Starobielsk trafił do gułagu na Kołymie, z którego został zwolniony dopiero w 1943 roku. Istner pozostał jednak na Syberii do końca wojny - pracował w kamieniołomach w Nowosybirsku i Krasnojarsku, a także - później - jako robotnik w kołchozie. Tuż przed repatriacją do Polski został zatrudniony jako nauczyciel w polskiej szkole w Aczyńsku, po czym szybko awansował na inspektora polskich szkół funkcjonujących w tym czasie w Rosji. Do Polski powrócił w 1946 roku. Na emigrację do Erec Israel udał się w roku 1968. Pracował tam jako redaktor w rosyjskiej redakcji radia Kol Israel. Wspomnienia z pobytu w Rosji wracają często w liryce Istnera, na przykład w wierszu Polonez As-dur z tomu To już (1989), będącym reminiscencją koncertu Artura Rubinsteina, wysłuchanego w Jerozolimie 20 września 1970 roku. Dźwięki wtedy usłyszane wywołały wspomnienia własnej historii (,wróciłem w pustkę snów niedomkniętych") i refleksje nad dwudziestowiecznym, podobnym jemu, losem żydowskim:

\footnotetext{
Obojętnie przechodzę aleją wawrzynów i mirtów

Mijam gaje oliwne

ze smakiem cykuty w ustach. Biała Kołyma.

Pozostał gryzący dym

Oświęcimia,

gdy dogasała słodka „Noc hiszpańska”

i słowiki kwiliły

wśród cyprysów de Falli.
} 
W tych poetyckich obrazach, spisywanych - paradoksalnie podczas podróży do Stanów Zjednoczonych, powraca okupowany przez Sowietów Lwów z budzącą wtedy trwogę ulicą Zamarstynowską i słyszanymi z celi więziennej jeżdżącymi po torach elektrycznymi tramwajami (zob. San Francisco I):

— Wspinał się później, jak widmo młodości —

Jakąś stromą ulicą.

Ale nie było tam sowieckiego więzienia z ślepymi

Oknami i kratami,

Więc nie był to Lwów.

W następnej cząstce tomu Istner konkluduje tę znaczącą w jego twórczości kwestię traumy sowieckiej, wpisując ją w koleje swojego życia:

Skąd przybyłem i dokąd zmierzam?

Z Polski? Z Jerozolimy? Z Kołymy?

Może po tej podróży dowiem się nareszcie

kim jestem

(San Francisco II)

Jedną z najtragiczniejszych postaci z kręgu przedstawianych tu pisarzy polsko-izraelskich był Leo Lipski, który we wrześniu 1939 roku w obawie przed nazistami przybył do okupowanego przez Sowietów Lwowa. Jednak już w 1940 został aresztowany przez NKWD i wywieziony do łagru nad Wołgą w pobliżu Uglicza. Pracował tam jako robotnik leśny, a następnie jako pomocnik obozowego lekarza. Wolność przyniósł mu układ Sikorski-Majski. Lipski wstąpił wtedy do armii generała Andersa, z którą został ewakuowany do Teheranu ${ }^{8}$. Pokłosiem pobytu w ZSRR była ciężka choroba neurologiczna, w jej wyniku sparaliżowany pisarz pięćdziesiąt lat swo-

\footnotetext{
${ }^{8}$ Por. H. Gosk, Jesteś sam w swojej drodze. O twórczości Leo Lipskiego, Izabelin 1998; tegoż, Wątek poszukiwania tożsamości w emigracyjnej prozie polskiej (na przykładzie utworów Zygmunta Haupta z tomów „Pierścień z papieru”, „Szpica” oraz Leo Lipskiego „Dzień i noc”, „Piotruś), „Przegląd Humanistyczny” 2000, nr 3; P. Krupiński, Leo Lipski - Homo Patiens na szlakach literatury, w: M. Dąbrowski, A. Molisak (red.), Pisarze polsko-żydowscy XX wieku. Przybliżenia, Warszawa 2006; M. Sambor [M. Chmielowiec], Pieśń o nieludzkiej ziemi, „Wiadomości” 1957, nr 17.
} 
jego życia spędził w łóżku. Okres pobytu w sowieckich obozach koncentracyjnych opisał w tomie opowiadań Dzień $i$ noc (1955), za który w tym samym roku otrzymał literacką nagrodę Kultury. Reminiscencje tamtych doświadczeń znalazły swoje miejsce także w powieści Piotruś (1960).

Inny pisarz polsko-izraelski, Jakub Perelman, po przedostaniu się na tereny polskie okupowane przez ZSRR, żył w przeświadczeniu, że będzie mógł spokojnie przetrwać tam całą wojnę (na początku był nawet kierownikiem szkoły we wsi Tobółki). Wkrótce jednak został zatrzymany przez NKWD pod zarzutem szpiegostwa i skazany na dziesięć lat pozbawienia wolności w więzieniach w głębi ZSRR. Na mocy amnestii uwolniony w 1941 zamieszkał w Bucharze (Uzbekistan). Udało mu się nawet początkowo znaleźć zatrudnienie jako nauczyciel, jednak szybko je utracił i poszedł do pracy jako robotnik odzieżowy. Tuż po wojnie powrócił do Polski, a potem wyjechał do Izraela. W 1977 roku w Hajfie opublikował obszerny tom osobistych wspomnień i refleksji Moje przeżycia, spostrzeżenia. Opisał w nim swoją traumę po pobycie w Związku Sowieckim, skrajną biedę jego obywateli, ich bardzo trudne warunki życia, a także panujący na terenie kraju głód. Podał przy tym wiele przykładów gospodarczej nieudolności komunistów, a także ich sprzeczny z założeniami internacjonalizmu — antysemityzm.

Kolejnym pisarzem, który przebywał w Rosji w czasie wojny, był Edward Neuman (Nejman). W Ałapajewsku na Uralu i w Borysowie pracował jako robotnik przy wyrębie lasów i w fabryce metalurgicznej. Kilkukrotnie zwalniany $\mathrm{z}$ więzienia i na nowo aresztowany, w końcu został skazany na pobyt łagrach. W 1947 wrócił do Polski. Do Izraela wyjechał w 1958 roku. Jest autorem wspomnień Cena przetrwania (1992), w których drobiazgowo przedstawił sowiecką rzeczywistość - absurdalne mechanizmy biurokratyczne, ubóstwo codziennej egzystencji, wszechobecny lęk mieszkańców ZSRR. Zrelacjonował także swoje zabiegi o to, by przeżyć. Porównał własne doświadczenia $\mathrm{z}$ losami poznanych w Rosji innych obywateli przedwojennej Rzeczpospolitej - Polaków i Żydów, którzy, wa cząc o przetrwanie swoje i swoich najbliższych, marzyli jedynie o powrocie do Polski. 
Łucja Pinczewska-Gliksman w czerwcu 1940 roku została deportowana do Kopiejska za Uralem, gdzie pracowała niewolniczo w kopalni węgla ${ }^{9}$. Zwolniona jesienią 1941 na mocy układu Sikorski-Majski, ostatni okres w ZSRR spędziła w Tadżykistanie. Po wojnie, wraz ze swoim mężem Jerzym Gliksmanem (prawnikiem i socjologiem, działaczem socjalistycznej żydowskiej partii Bund), opracowała wydaną w 1948 roku monografię na temat sowieckich łagrów: Tell the West. An Account of His Experiences as a Slave Laborer in the Union of Soviet Socialist Republics (wkrótce przetłumaczoną na język polski i wydaną w Nowym Jorku w roku 1951 pod tytułem Powiedzcie Zachodowi. Wspomnienia autora z okresu niewoli w obozie pracy przymusowej w Związku Sowieckich Socjalistycznych Republik). Miała tragiczne doświadczenia z przymusowego pobytu w ZSRR, a także świadomość ogromu zbrodni dokonanych tam na obywatelach polskich, w tym Żydach, jednak sama Rosja była do końca życia jedną z jej największych fascynacji. Swoje slawistyczne studia językoznawcze na Uniwersytecie w Chicago poświęciła literaturze rosyjskiej - mając doskonale opanowany język rosyjski prowadziła w USA zajęcia dydaktyczne z zakresu historii Rosji. Wykładała także literaturę rosyjską na Roosevelt University. Później pracowała w Russian Research Center na Harvardzie, gdzie prowadziła dalszą działalność naukowo-dydaktyczną. W Ameryce wiele publikowała w zakresie współczesnej literatury rosyjskiej (po 1917 roku). Wraz z mężem opracowała też dla instytutu badawczego The RAND Corporation raport A Study of the Value of Soviet Fiction, w którym wykorzystała teksty literackie jako źródła opisu współczesnego życia w ZSRR. Po przejściu na emeryturę zamieszkała w Izraelu, wtedy też opublikowała swoje najważniejsze prace literackie.

${ }^{9}$ Zob. S.J. Żurek, Na krawędzi światów, w: Ł. Pinczewska-Gliksman, Na aryjskich papierach, Jerozolima-Lublin 1996; tegoż, Głos odchodzacego pokolenia, „Kultura” 1998, nr 11; O antysemityzmie, Leo Lipskim i „Ludziach z MaisonsLaffitte” (rozmowę z Łucją Pinczewską-Gliksman przeprowadził S.J. Żurek), „Tygiel Kultury” 1999, nr 7-9; tegoż, Łucja Pinczewska-Gliksman, w: Z. Dybciak, K. Kudelski (red.), Leksykon kultury polskiej poza krajem od roku 1939, Lublin 2000 . 


\section{Uchodźcy}

Największą grupę spośród przyszłych pisarzy polsko-izraelskich stanowili ci, którzy w latach drugiej wojny światowej starali się żyć normalnie na terenach Rosji sowieckiej i ani nie angażowali się ideowo w komunistyczny system, ani nie znaleźli się w więzieniach i łagrach.

I tak Ruth Baum przeżyła całą wojnę, pracując jako robotnica najpierw na wschodniej Ukrainie, a później na Uralu, ucząc się jednocześnie w wieczorowym gimnazjum (tzw. sowieckiej dziesięciolatce). Ta późniejsza pisarka polsko-izraelska debiutowała właśnie w ZSRR przetłumaczonymi na rosyjski opowiadaniami, które zostały opublikowane w gazecie codziennej „Wołoszyło-gradzkaja Prawda”. Potem w Izraelu okres pobytu w Kraju Rad stał się też tematem ogłoszonej, pierwotnie w odcinkach w „Nowinach-Kurierze”, następnie w formie książki, powieści Trzynasty miesiąc roku (1977). Jej bohaterka to młoda kobieta, która przybywa do ZSRR z okupowanej Warszawy. Powieść ta jest autobiograficznym świadectwem dojrzewającej w sowieckiej Rosji polskiej Żydówki, która zmaga się z trudną codziennością przeżywaną w państwie totalitarnym.

Bezpośrednio przed wybuchem drugiej wojny światowej przyjechała z Nowego Sącza do Lwowa Ilana Maschler. Po aneksji wschodnich terenów Rzeczpospolitej przez ZSRR pracowała m.in. jako ekspedientka w sklepie spożywczym i sekretarka w cegielni. Pod koniec czerwca 1941 wraz z rosyjską ludnością cywilną ewakuowała się z mężem poza linię frontu - do Dniepropietrowska, a następnie do oddalonego od tego miasta około trzydziestu kilometrów Nowomoskowska. Uciekając przed ofensywą niemiecką, dotarli aż do Piatigorska, potem na Kaukaz, m.in. do Erewania i do Groznego (gdzie byli świadkami masowych deportacji Czeczenów i Inguszów). Jako Żydzi początkowo nie zostali przyjęci do Polskich Sił Zbrojnych w ZSRR. Jednak gdy w 1943 zgłosili chęć przyłączenia się do 1 Korpusu PSZ w ZSRR, tzw. Armii Berlinga, wiosną 1944 zostali doń włączeni. Potem wrócili do Polski, z której wyemigrowali do Izraela w 1948. W 1994 roku Maschler wydała w Warsza- 
wie, nakładem wydawnictwa Krupski i S-ka, tom wspomnień Moskiewski czas. Książka ma charakter dokumentarno-literacki (fakty historyczne przeplatane są fabularyzowanymi anegdotami ilustrującymi codzienność w systemie sowieckim). W zakresie stylistyki dominuje tu dyskurs ironiczny (narrator nakłada maskę „człowieka radzieckiego”) z mocno zaakcentowaną krytyką systemu i współczuciem dla jego ofiar (aresztowania, wywózki w głąb Rosji, głód).

$\mathrm{Na}$ terenie Rosji w czasie wojny znalazł się również Jakub Kost. Od 1943 roku walczył jako oficer w Armii Berlinga, z którą doszedł do Berlina ${ }^{10}$. Do Izraela przyjechał wraz $\mathrm{z}$ żoną i synem w roku 1957. W swojej jedynej książce - powieści historycznej Ksiądz Zygmunt (1984) pojawia się scena pokazująca, jak pod koniec wojny ksiądz prosi sowieckiego oficera, który jest Żydem, aby ten zaprowadził żydowskie dzieci do bożnicy na modlitwę Izkor. Duchowny nie chce bowiem, by te straciły więź ze swoją tradycją religijną (ma pogłębioną świadomość, że chrześcijanie i żydzi wierzą w tego samego Boga). Sowiecki żołnierz - co wydaje się w świetle powszechnych doświadczeń niemożliwe - księdzu nie odmawia.

Jako dzieci przebywali w ZSRR również tacy późniejsi autorzy izraelsko-polscy jak Henryk Palmon (Figielm) i Aleksander Rozenfeld. Pierwszy z nich skończył tam pięć klas szkoły powszechnej. Swoje dziecięce doświadczenia opisał w powieści Wielka wojna małego i dużego Chaskiela (1998), w której występuje pierwszoosobowy narrator patrzący na świat oczyma kilkunastoletniego chłopca. Ów narrator-bohater, tytułowy Chaskiel, opowiada o swoich traumatycznych przeżyciach wojennych żydowskiego dziecka mieszkającego najpierw w Polsce, a później w ZSRR. Rozenfeld natomiast przyszedł tam na świat w rodzinie o przekonaniach komunistycznych ${ }^{11}$. Motywy rosyjskie kojarzone $\mathrm{z}$ wczesnym dzieciństwem często pojawiają się w wielu jego tekstach poetyckich.

${ }^{10} \mathrm{~W}$ wojsku polskim tworzonym przez komunistów w ZSRR znaleźli się także: Jan Kot, Herbert Friedman, Eleasar Feuerman (Jerzy Pogorzelski), Noe Wertheiser (Michał Tonecki).

${ }^{11}$ Zob. Rozenfeld $w$ trybach historii. Z Aleksandrem Rozenfeldem rozmawia Anna Jarmusiewicz, Warszawa 2010. 
Sprawa rosyjska w literaturze polskiej w Izraelu to przede wszystkim kontekst przeżyć biograficznych jej twórców. Polscy Żydzi wracali z ZSRR w stanie ambiwalencji, z jednej strony — wdzięczni losowi, że udało im się przeżyć, a z drugiej — porażeni traumą komunizmu. Jednak tamta ziemia, jej kulturowe dziedzictwo, w niektórych wypadkach, zapadała w serce jako obiekt nieprzeniknionego urzeczenia.

\section{Славомир Яцек Журек}

Резюме

\section{РУССКИЙ ВОПРОС В ПОЛЬСКОЙ ЛИТЕРАТУРЕ В ИЗРАИЛЕ. ОБЗОР}

Русский вопрос в польской литературе в Израиле это, прежде всего, контекст биографических переживаний ее создателей. Советская Россия это место казни, но одновременно место спасения многих польских евреев - важных польско-израильских писателей и поэтов. Автор статьи подразделяет их на идейных коммунистов, узников лагерей и выходцев. Опыт пребывания в СССР стал для них важной литературной темой, а сама Россия - парадоксально - часто объектом их увлечения.

Sławomir Jacek Żurek

Summary

THE RUSSIAN PROBLEM IN POLISH LITERATURE IN ISRAEL. REVIEW

The Russian problem in Polish literature in Israel is first of all concerned with experiences of the writers. The Soviet Russia was on the one hand a place of torment and torture, but on the other it was a chance for may Polish Jews (significant Polish-Israeli writers) to survive. According to the author the writers were either ideological communists, camp prisoners or refugees. The time they spent in the Soviet Union was an inspiration for their literary works, and Russia - paradoxically - was a source of great fascination. 